\title{
DELIVERY IN ESCROW AND THE PAROL EVIDENCE RULE
}

\author{
Henry W. Ballantine \\ Dean of the College of Law, University of Illinois
}

Something of an air of mystery and fiction pervades the subject of escrows and obscures the question how far the transfer of title by absolute deed may be suspended by parol conditions imposed on the delivery. The desired effect of an escrow might, in many cases, be more safely attained by writing the express condition precedent upon the face of the deed. The instrument could then be delivered direct to the grantee. Such express condition might be an event certain to occur, as the death of the grantor, or an uncertain one, as the payment of the purchase price. If the condition is sure to happen, the interest of the grantee would be either a vested remainder or a certain executory interest; if uncertain, the interest given would be a contingent executory future interest. ${ }^{x}$ The objection to inserting such conditions precedent in deeds is of course that of introducing uncertainty into the record title and the danger of casting a cloud on the title of the grantor.

Conditional delivery is a device to put an absolute instrument into effect subject to an external or parol condition precedent, and thus to suspend the acquisition of the interest which the instrument purports to create. It is a substitute for an express condition precedent on the face of the deed, and thus may conflict with the legislative policy underlying the parol evidence rule. ${ }^{2}$ In the case of a will, the contingency must be expressed in the instrument itself if its operation is to be made contingent. ${ }^{3}$ In the case of a deed advantage is taken of the fact that the instrument depends for its operation upon delivery, a matter in pais.

The writing, signing and sealing of a document do not of themselves make it an "operative" instrument, not even if it be attested and acknowledged. Neither does the placing of a deed in the hands of the grantee or obligee for a temporary or special purpose per se constitute a delivery. Parol evidence is always admissible to show that the document was never put into effect or beyond the rightful control of the grantor, though it was handed over to the grantee himself. "In such cases the inquiry is: What was the intention of the parties at the time? And that intention, when ascertained, must

${ }^{1}$ Thomas $v$. Williams (1908) IO5 Minn. 88, II7 N. W. 155.

${ }^{2}$ Taft $v$. Taft (I886) 59 Mich. 185, 26 N. W. 426.

- I Alexander, Commentary on Wills (I9I7) secs. I02, II2; see Noble v. Fickes (Ig07) 230 I11. 594,82 N. E. 950. 
govern." 4 The question of delivery is something aside from the writing in an instrument. It depends upon proof by parol, and the evidence arising from possession of the deed by the grantee may be rebutted by parol. ${ }^{5}$ Parol evidence is always necessary to prove words or acts of the maker expressing his intention to make the instrument "operative."

Delivery is a declaration or expression of intent that an instrument shall become binding or go into legal effect. Absolute delivery is a declaration that the instrument shall go into effect presently according to its terms. Conditional delivery is a declaration that the instrument shall go into effect according to its terms at a future time. A conditional delivery is one by which it is declared that the instrument shall not produce the change of legal relations in respect to property which it purports on its face to do, until something occurs. This something may be an event certain or uncertain. "Conditional" broadly includes suspension of effect not only by uncertain future acts and events but also by certain or inevitable future events such as death. In either case the declaration of intent may be regarded as an immediately operative legal act, binding on the grantor and giving a present interest to the grantee qualified by the parol condition.

If the condition upon which the deed is deposited is one certain to occur, the delivery is usually regarded as not being conditional at all. ${ }^{8}$ The authorities make much of the distinction between cases where the delivery is made to depend upon the payment of money or the happening of some uncertain contingency and cases where there is no condition connected with a delivery except a future event sure to occur, like the death of the grantor. It is generally held where a deed is delivered to a third person to be handed to the grantee on the grantor's death, that the deed will operate as a present conveyance. ${ }^{7}$ The deed is held to create immediately a vested future estate subject to a life estate left by subtraction in the grantor. By the oral qualification placed on the delivery, the grantor impliedly reserves to himself a life estate just as he would by an express provision in the deed suspending its operation until his death. Thus in Smith v. Smith deeds were deposited with an attorney of the grantor with written directions for the depositary to deliver them "upon my death, so that they may then take effect." It was held that this did not prevent the present passing of title at the time of depositing the deeds, if on all

\footnotetext{
See Jòrdan v. Davis (1883) I08 I11. 336; Wilson v. Wilson (I895) 158 I11. 567, 4I N. E. I007; Sample v. Geathard (1917) 28I I1l. 79, II7 N. E. 7I8.

'Jordan v. Davis, supra; Nofftz v. Nofftz (19r9) 290 Ill. 36, 42, I24 N. E. 838; Pollock v. Glassell (1846, Va.) 2 Gratt. 439, 445.

'Prutsman v. Baker (1872) 30 Wis. 644, II Am. Rep. 592.

${ }^{7}$ Whitney v. Shernan (1918) I78 Calif. 435, I73 Pac. 931; Smith v. Smith (I916) I73 Calif. 725, I6r Pac. 495; Hunt v. Wicht (I9I7) I74 Calif. 205, I62 Pac. 639, L. R. A. I917C 961 ; Bullard v. Suedmeier (1920, Ill.) 126 N. E. II7.

${ }^{8}$ Stupra.
} 
the evidence the directions referred to the time of enjoyment, rather than to the passing of title.

In such cases the delivery is in terms conditional, yet since the grantor has parted with control over the deed, and since the grantee's rights are dependent only upon a certain future event, he may be regarded as having a vested future estate, and the grantor's interest may be regarded as being immediately cut down correspondingly. This explains the puzzle how a life estate in the grantor can be created by a juggling of delivery and how parol conditions or reservations may vary and modify the estates which an instrument purports to create. ${ }^{10}$

It is commonly said in case of the deposit of a deed in escrow to be delivered to the grantee on performance of some condition that the instrument has no effect as a deed and passes no interest to the grantee prior to the second delivery. ${ }^{12}$ These statements are misleading. One must be on his guard to avoid taking the language of the courts or of the parties too literally. While it is true that deposit in escrow does not divest the grantor of his "title" it does create a change in the legal relations between the grantor and the grantee with reference to the land. If $B$ does nothing, title remains in A. If $B$ performs the condition, title passes to him. Where the condition is a future voluntary act of the grantee, the deed creates an irrevocable power in the grantee to draw the title out of the grantor. Where the condition is any other event, the deed creates an irrevocable conditional interest in the grantee. An escrow prior to the performance of the condition is therefore not a mere paper like a will before the death of the testator. It changes legal relations. It is not a mere draft of a deed or an executory contract to convey, but is a deed presently with a definite legal operation. Every act necessary to a complete operative deed must be done by the grantor, who delivers the escrow deed to a third person subject only to a condition precedent suspending transfer of the complete and unconditional property interest. ${ }^{12}$

\footnotetext{
- Ballantine, When are Deeds Testamentary? (1920) 2 Ir. L. BuL 46r, 466; 3 Washburn, Real Property (6th ed. 1902) sec. 2177. By "title," as used here, is meant that portion of the total "property" known as a vested remainder.

${ }^{10}$ Aigler, Is a Contract Necessary to an Effective Escrow? (I918) $16 \mathrm{MICF}$. L. REv. 569, 586, note ("How a life estate in the grantor can be created by a juggling of delivery is a question never adequately answered."); Bigelow, Conditional Deliveries of Deeds of Land (1913) 26 HARv. L. REv. 565, 577; Tiffany, Conditional Delivery of Deeds (I9I4) I4 CoL. L. REv. 389, 404-405.

"Whitney v. Dezvey (rgo5) Io Ida. 633, 80 Pac. III7; 3 Washburn, op. cit., secs. $2175,2177$.

${ }^{22}$ Roach v. Malone Co. (I9I8) I35 Ark. 69, 204 S. W. 971; "Delivery must be so complete that it only remains for the grantee or obligee to perform the condition or for the event to happen to give the instrument full effect." Schults $v$. Schults (1895) I59 I11. 654, 43 N. E. 800; Schmidt v. Frastkfort (I902) I3I Mich. 197, gr N. W. 131; Davis v. Brigham (rgro) 56 Ore. 4I, 107 Pac. 96I, Ann. Cas. I912B 1340 ; Nation v. Green (I9I9, Ind.) r23 N. E. I63. See also CommenT (Ig20) 29 Yale Law Journal, 549.
} 
As is said in the oft-quoted passage from Butler $\&$ Baker's Case:

"To some intent the second delivery hath relation to the first delivery, and to some not; and yet, in truth, the second delivery hath all its force by the first delivery, and the second is but an execution and consummation of the first."13

In fact the second delivery is no part of the delivery at all. When the condition is performed the depositary becomes the custodian for the grantee and the deed takes full effect without any formal second delivery- As the court well says in the case of Craddock . $_{\text {. Barnes, }}{ }^{1 *}$

"Some courts hold that an escrow does not take effect as a fully executed deed until there has been a rightful delivery to the grantee; but the logical position approved in a number of authorities is that it is effective as a deed when the grantor relinquishes the possession and control of it by delivery to the depositary, and it passes the title to the grantee when the condition is fully performed, without the necessity of a second delivery by the depositary."15

It is then the performance of the condition and not a second delivery which is operative to pass title, or rather to render the conditional interest of the grantee absolute. It is the first delivery which gives the deed vitality. When a deed is delivered as an escrow, it is no longer revocable by the maker, but will operate to pass title whenever the condition happens upon which it is to have full effect. The result then is much the same as where there is an absolute delivery to the grantee with a condition precedent expressed on the face of the deed.

The courts generally have failed to understand the true mature of conditional delivery. As Professor Hohfeld has well pointed out in his notable article on Fundamental Legal Conceptions,

"Fundamentally considered, the typical escrow transaction in which the performance of conditions is within the volitional control of the grantee, is somewhat similar to the conditional sale of persomalty. . . . Once the 'escrow' is formed, the grantor still has the legal titlle; the grantee has an irrevocable power to divest that title by performance of certain conditions ( $i$. e., the addition of various operative facts), and concomitantly to vest title in himself. While such power is outstanding, the grantor is, of course, subject to a correlativive liability to have his title divested ${ }^{\text {m16 }}$

\footnotetext{
II (I59r, K. B.) 2 Coke, 68

14 (1906) 142 N. C 89, 54 S. E. 1003-

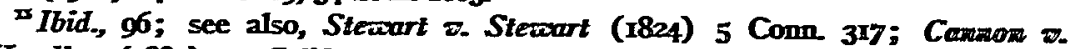
Handley (1887) 72 Calif. 133,13 Pac 315; Farley v. Palmer (18\%0) 20 Oh. St. 223.

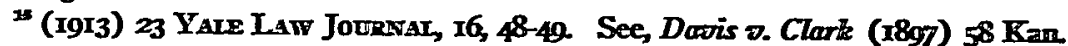
100, 48 Pac 563; Leifer च. Pike (1889) v27 Ill 287, 326, 20 N. E 23; Hunter ฮ. Hunfer (1854, Sup. Ct. N. Y.) x7 Barh. 25; Farley o. Palmer, supra; Hudsom \& Man. $R . R$ v. State (1919, N. Y.) 125 N. E 202; Ames, Lectures on Legal History (1913) 257.
} 
A by depositing the deed with $\mathrm{X}$ in escrow has given $\mathrm{B}$, the grantee, an irrevocable power to earn or acquire the title by performing the condition. The deed, perfect on its face and requiring no further act on the part of the grantor, gives a contingent right to $B$, which, when it later vests, may be said to "relate back," so that the purchaser's title goes back to the date of the original delivery in escrow. He has a power and the grantor is subject to a liability from the start. In some degree then, the escrow deed has an immediate operation as a deed, although its full effect is suspended. ${ }^{17}$

This theory of the nature of delivery in escrow explains the so-called fiction of relation back by which an escrow deed is held to operate for certain purposes from the time of its first deposit. Relation back is, according to this theory, not a fiction at all. It is simply a description of the fact that the grantee acquires some species of power or contingent property interest $a b$ initio, which is not affected by subsequent transactions or events such as death, incapacity, or transfers of title of the grantor. ${ }^{18}$

The grantor as it were holds his estate in fee subject to an executory limitation. He has the same rights, privileges, etc., in general, as if he were absolute owner, and the so-called title may be transferred by his act or by operation of law, subject to the liability of termination in the hands of the transferee. All persons claiming under the grantor are likewise subject to the liability created by the conditions of the escrow, unless protected by the recording acts. ${ }^{19}$ The deposit of a deed in escrow is then a completed legal act, irrevocably operative, though its full effect as a conveyance is postponed and contingent. ${ }^{20}$ The performance of the condition by the grantee is a necessary operative fact, but this is merely as the execution of the power which vests the "title" or estate. The delivery of the deed has already a legal operation without it in creating the power.

A very important question in regard to escrows which has been frequently arising, is whether an escrow arrangement will be revocable by the grantor unless supported by a binding contract of purchase and sale. In some states it has been held that it is not necessary that there should be a previous binding contract to convey. ${ }^{21}$ It is the

\footnotetext{
${ }^{17}$ Hunter v. Hunter, supra, 81, 82; Farley v. Palmer, supra; see CoMment (I920) 29 YALE LAW JournaI, 549.

${ }^{18}$ Nolan v. Otney (I907) 75 Kan. 3II, 89 Pac. 690, 9 L. R. A. (N. S.) 3I7; Davis v. Clark, supra; cf. Tiffany, op. cit., 4or.

${ }^{12}$ Leiter v. Pike, supra; cf., however, May v. Emerson (I905) 52 Ore. 262, 96 Pac. I065; Wilkins v. Somerville (1907) 8a Vt. 48, 66 Atl. 893, 130 Am. St. Rep. 906, note.

${ }^{20}$ Chadzerick v. Tatem (1890) 9 Mont. 354, 23 Pac. 729; Tiffany, op. cit., 401.

${ }^{21}$ Hall v. Harris (1848) 40 N. C. 303; Farley v. Palmer, supra; Whitfield v. Harris (1873) 48 Miss. 710; Dettmer v. Behrens (1898) I06 Iowa, $585,76 \mathrm{~N}$. W. 853; Tharaldson v. Evarts (I902) 87 Minn. 168, 9x N. W. 467.
} 
view of able writers that this should be the law. ${ }^{22}$ The current of recent authorities, however, has set strongly in the direction of the rule that to uphold an escrow, that is, a delivery upon an uncertain condition precedent to be performed by the grantee, there must be a concurrent or preëxisting contract of sale to make the deposit irrevocable. This doctrine seems to take its rise largely from a California case followed by a Wisconsin case. ${ }^{23}$

It is of course true that the conditions upon which a deed is delivered in escrow may be proved by parol evidence, if there is a valid binding contract to convey. ${ }^{2 *}$ But should any written contract be held necessary to support an escrow? Is a deposit of a deed in escrow to be delivered on payment of the price the same in legal effect as a covenant to execute a deed on payment of the price? Is the effect of an escrow the same as a contract, merely to vest an equitable interest in the purchaser, and is giving effect to it by law simply a legal short-cut to specific performance? This is the theory of Professor Bigelow. ${ }^{25}$

A deposit in escrow under an oral contract to convey might be regarded as a conditional delivery and a performance of a contract to convey, leaving no executory covenant within the statute of frauds. But if the interest of the grantee is regarded as depending entirely upon a contract and the contract is oral, the deed deposited in escrow will not satisfy the statute of frauds. ${ }^{26}$

An escrow has been defined as a legal document which is to have no immediate effect but is only to come into operation upon the condition. ${ }^{27}$ An escrow might better be defined as a deed delivered to a third person upon an oral or extrinsic condition precedent. It would seem then that the result and operation of escrows should be much the same as if the condition precedent were expressed in the deed itself. An escrow should not be held to rest on the obligation of a contract, but the deed operates without further act or delivery

\footnotetext{
${ }^{2}$ Tiffany, op. cit., 389, 398, 452; Aigler, op. cit., 569; see also (1918) 27 Y ALE LAW JoURNAT, 699.

${ }^{2}$ Fitch v. Bunch (1855) 30 Calif. 208; Campbell v. Thomas (1877) 42 Wis. 466; see also, in accord, Holland v. McCarthy (I9I6) i73 Calif. 567, I60 Pac. 1069; McLain v. Healy (I9I7) 98 Wash. 489, I68 Pac. I, (I9I8) 27 YALE LAW JournaL, 699; Seifert v. Lanz (1914) 29 N. D. I39, I50 N. W. 568; Foulkes v. Sengstacken (19I7) 84 Ore. II8, I63 Pac. 3II; Main v. Pratt (IgI6) 276 Ill. 2I8, II4 N. E. 576; Davis v. Brigham, supra; Thomas v. Birch (1918) 178 Calif. 483, I73 Pac. II02.

${ }^{24}$ See Osby v. Reynolds (1913) 260 I11. 576, 103 N. E. 556; Manning v. Foster (I908) 49 Wash. 54I, 96 Pac. 233, I8 L. R. A. (N. S.) 337, note.

${ }^{25}$ Bigelow, op. cit., 565; see also, Wyatt v. Meade County Bank (1918) 40 S. D. III, I66 N. W. 423 .

${ }^{2}$ McLain v. Healy, supra; Kopp v. Reiter (1893) I46 I1l. 437, 34 N. E. 942. For a criticism of this view see (IgI8) 27 YALE LAW Journal, 699.

${ }^{27}$ Foundling Hospital v. Green [rgII] 2 K. B. 567, 573.
} 
by the grantor or depositary, just as if the condition were expressed in the deed and the deed delivered direct to the grantee. The delivery to a third party is, as we have seen, a substitute for the insertion of the condition as part of the deed, and operates to create an exception to the parol evidence rule.

No doubt the courts have been influenced in their present tendency to require a contract to uphold escrows by an instinctive hostility to this method of evading the statute of frauds and the parol evidence rule. There is a strong policy against having contracts and conveyances of land rest any more than is necessary in parol, or having title depend upon the performance of unwritten conditions.2s

In considering escrows the distinction should be noted between conditions which are uncertain because they consist of some voluntary act of the grantee or obligee, and conditions which are other uncertain events such as the survivorship of the grantee or the act of a third person. The former class is the typical escrow, and creates in the grantee an irrevocable power by performing the condition to extinguish the interest of the grantor and create a similar interest in the grantee, at least in cases where the grantor is under a contract duty to convey. The second class of conditions is held by some courts to create a conditional title or interest (not merely a power) in the grantee; but many courts hold that in such cases there is no operative delivery at all. ${ }^{20}$ Thus in Stone $v$. Dailey ${ }^{30}$ it was held that if a deed is handed to a third person who is instructed to keep the deed until the death of either the grantor or the grantee and then to deliver it to the survivor, the delivery is not effectual to give life to the instrument. It is said in Weber v. Brak,

"If a deed be delivered to a third person with the intention that it shall become operative only upon certain contingencies there is no delivery. A delivery must be unconditional, unless in escrow. There can be no partial delivery."

Thus if delivery to a depositary is conditioned to take effect upon the grantor's non-recovery from a particular illness or danger, it is said there is no valid delivery, as the grantor has not parted with control of the deed ${ }^{3 x}$

It may be pointed out that the provision that the deed is not to

\footnotetext{
3Chaddoür v. Witt (1919, Wis.) 174 N. W. 925; Taft v. Taft, supra; cf. NoIcta D. Otreer, supra.

$\Rightarrow$ Canzpell v. Thomas (1877) 42 Wis. 437; Smith v. Sinith, supra; Stone v. Dailley (r919, Calif.) 185 Pac 665; Weber v. Brak (1919) 289 Ill 564, 124 N. E. 654, (r920) 29 Yaiz Law Jourata, 550.

Sxpion.

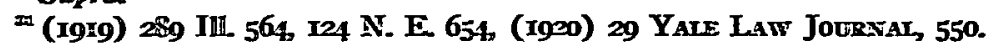

It Itid., 568-569.

Willams వ. Dazbner (1899) 103 Wis. 521, 79 N. W. 748; Prutsman च. Baker, supre.
} 
thalle effect in the ewent of the gramtee's dying before the grantor, or recoverimg from a particullar illmess, does mot sthow thati the grantor did

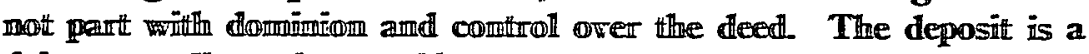

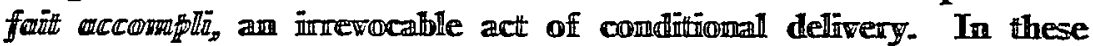
cases mamy countts comfunse the qurestion wilhether tiulle is to pass at once with the qurestion whether there is a presemt delivery. The idea that the gramitar retaims combroil because tirtle is ta pass only on a contingency is a purely grattunitous assumuption: ${ }^{32}$

Am opverative dellivery sthould be helld to exist if the grantor bas expressedi a clear intemtiom to retain mo pourer over the subsequent Iegall opperattiom of the instrumemit. By comdintiomall delivery the grantor

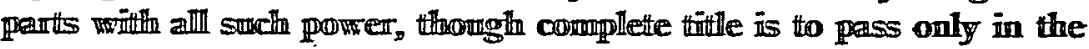

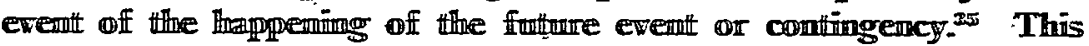

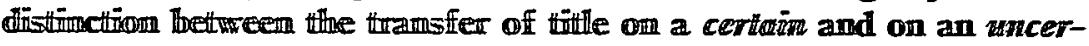

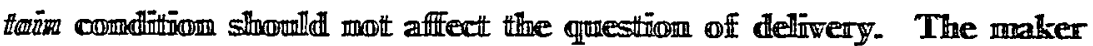

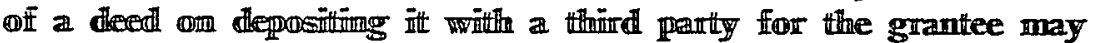

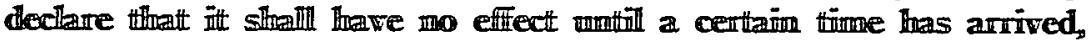
or antifll some wmcertainm contingency has happemed. The grantor sthoulld be thoumd by the dielinery in eitther case. The condiftion does

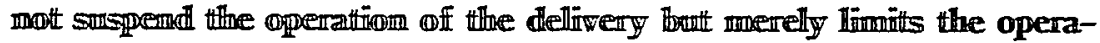
triom off the deed so as mot to tramsfer complete tittle. Where the contingemcy is am moncertain act, thowrever, wre thenve seen that the current

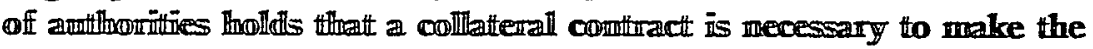

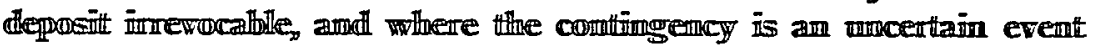
it is thellit thent there is mo "wallidil delliwery" att alli.

IVIe mow come to comsinter the qumestiom of dellivery direct to the

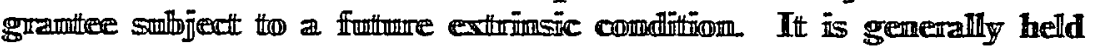

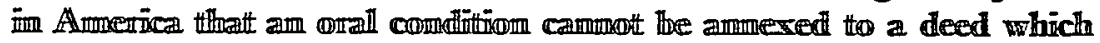

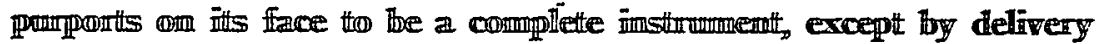

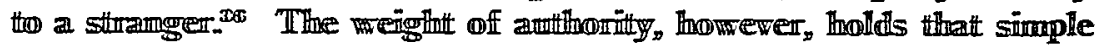

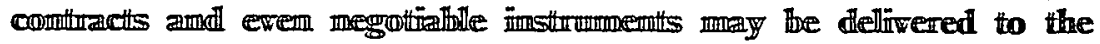

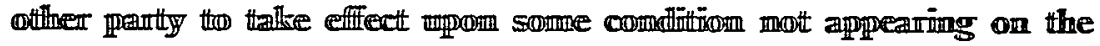

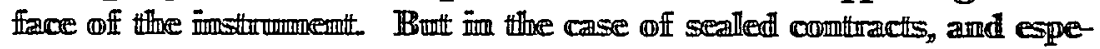

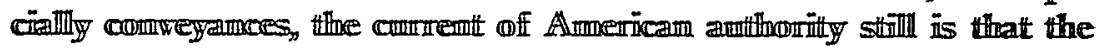

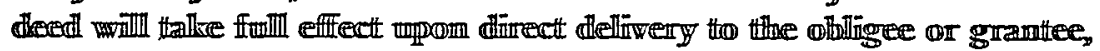

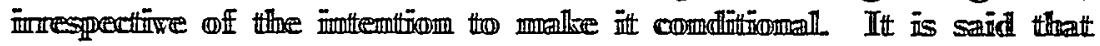

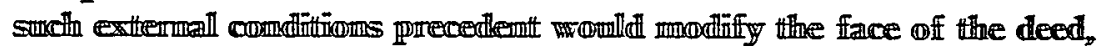

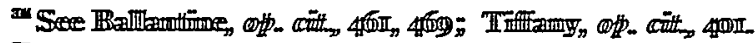

${ }^{25}$ N⿴囗十

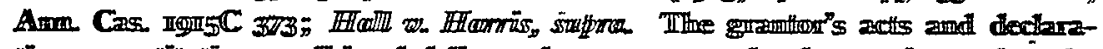

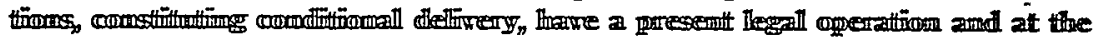

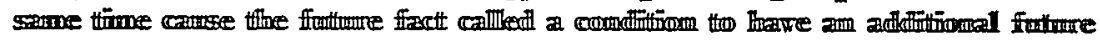
Ilegeall operattīm.

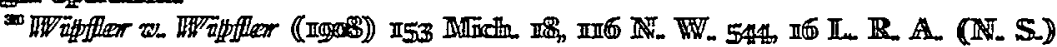

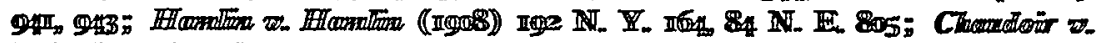

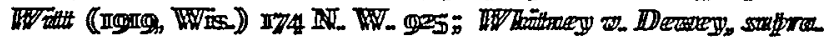


and read into it conditions which may operate to affect the title to realty. ${ }^{37}$

"Titles would be open to attack at all times, and the practical result would be to defeat the solemn provisions of a duly executed and formally delivered deed by parol testimony." 38

In modern English cases this rule has been largely overthrown, and parol evidence of conditional delivery is allowed as proof that no simple contract or deed had in fact been made except upon the parol condition. The presumption arising from possession of a document by the obligee or grantee may be overcome by showing that the signed paper was never intended to be the complete record of the terms of the existing agreement. ${ }^{39}$ In New York the rule against conditional delivery to the party himself is confined to instruments relating to title to real estate. ${ }^{40}$

This rule is criticized by eminent authority as an arbitrary and unjust one, that "no reason and no policy justifies it." ${ }_{41}$ It has been asserted that this is a striking instance of a survival of a formalistic doctrine (explained by the relation between delivery of deeds of conveyance and primitive modes of conveyance) regarding which English courts have shown a more enlightened view than have courts on this side. ${ }^{22}$ These critics go on the assumption that by conditional delivery no legal act has been consummated till the condition occurs. This assumption we have seen to be a mistaken, or at least a very questionable, one. Dean Wigmore speaks of a delivery in escrow as having "long been recognized as leaving the act incomplete; though here it may well be that the document cannot be withdrawn, since nothing but the condition remains to complete the act."43 As Professor Corbin ${ }^{44}$ has pointed out, it is unfortunate to speak of the occurrence of the condition as the completion of any act or utterance on the part of the grantor or obligor. The delivery of the document in escrow is an irrevocably completed act. The document is thereby

${ }^{s 7}$ Bigelow, op. cit., 585; Taft v. Taft, supra.

${ }^{35}$ Chaudoir v. Witt, supra, 925-926.

${ }^{3}$ Pym v. Campbell (I856, Q. B.) 6 E. \& B. 370, (I9I9) 28 YAle Law Jourial, 766; Hudson v. Revett (I829, C. P.) 5 Bing. 368.

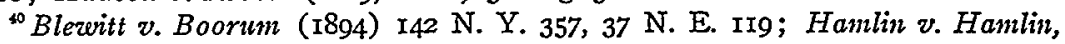
supra; Hovey v. Hovey (I9I7, Sup. Ct.) I70 N. Y. Supp. 822; Higgins v. Ridgway (1897) I53 N. Y. I30, 47 N. E. 32 ; cf., Holbrook v. Truesdell (1904) 100 App. Div. 9, 90 N. Y. Supp. 9II; Doughty v. Weston (19I6) I72 App. Div. 905, I60 N. Y. Supp. 1075 .

${ }^{41}$ Wigmore, Evidence (rgo5) sec. 2408; 2 Page, Contracts (2d ed. I920) sec. I205.

(I920) I8 MICr. L. Rev. 314, 3I6. See also 4 Wigmore, op. cit., secs. 24002408.

${ }^{23} 4$ Wigmore, op. cit., sec. 2408.

" Corbin, Conditions in the Law of Contract (IgIg) 28 Yale Law Journal, 739,765 . 
put into effect as an operative instrument, though certain of its legal effects are subject to a condition precedent. The occurrence of the condition is not the completion of any act, but simply one of the operative facts upon which a fully executed instrument is to have a certain legal effect. ${ }^{45}$ It has operative effects from the moment of deposit in escrow or delivery on condition, but the rights given are rendered conditional by reason of the qualification of the delivery.

An escrow then would seem to be in fact a real exception to the parol evidence rule that oral testimony will not be admitted to vary or to contradict the purport of a legal instrument which has once been delivered and made operative. The condition, though in form a condition to the existence or binding force of the document, is in reality a condition to the rights given by the document, a qualification of the grant. When delivery is intended to give binding force to a deed without further act or expression of assent by the grantor, then to incorporate parol conditions does in effect vary and contradict the terms of the written instrument. ${ }^{40}$ No further act of the grantor is needed. No power to control or recall the deed remains in him. To show the parol conditions makes the transaction rest partly in parol as to matters which might be expressed on the face of the deed. The frequent conflict of cases in the same jurisdiction shows the difficulty which the courts have with the parol evidence rule in its application to conditional delivery. It is exceedingly difficult to draw the line between conditional delivery, non-delivery, and collateral contract.

There is great confusion in the cases dealing with the effect of delivery of a deed to the grantee to take effect at the death of the grantor. In Mozery v. Heney $y^{47}$ an absolute deed of certain property was delivered to the grantee upon an understanding that the deed was not to be operative in event of recovery of the grantor from a certain illness. The grantor recovered, but the deed was held an absolute conveyance, operative from the first, without regard to the understanding or intention of the parties. Works, J., applied the traditional rule which refuses to recognize delivery in escrow to the grantee. He held that it would be a dangerous violation of the parol evidence rule to allow proof that the deed was delivered to the grantee to take effect upon the happening of a future contingency; and that an absolute deed which has been delivered to the grantee, cannot have its operation defeated by parol proof of an intention on the part of the grantor, known to the grantee, that it should not take effect except in event of the grantor's death. McFarland, J., dissented on the ground that there was no delivery at all. The case of Mowry

\footnotetext{
${ }^{4}$ Norman v. McCarthy' (I9r3) 56 Colo. 290, I38 Pac. 28; Riley v. International Co. (Igr4) I85 Ill. App. 629; see Aigler, op. cit., 314.

"Ordinary of New Jersey v. Thatcher (1879) 4I N. J. L. 403, 32 Am. Rep. 225; Tiffany, op. cit., 405.

"(I890) 86 Calif. 471, 25 Pac. I7.
} 
v. Heney has been followed by the California court in some other cases including Hannzuond $\nabla$. McCollough $h_{s}$ in which it was held that delivery of a deed from one spouse to another, with the wnderstanding that it was to be destroyed on the grantee's dying first, would be given strict legal effect as absolutely vesting tittle in the gramtee. It is not competent to prove by parol an agreement comirary to the planim import of the instrument, or that it is to have effect only on some conditition or contingency. ${ }^{\circ}$

It is difficult to hamonize with these cases the hold ing in Kenney v. Parks.50 In this case a wife gave her husband two deedts winder the representation and bellief that they would not be valid writil recorded, and upon her hushemd's promise that he would mot record them uniless. he survived her. He recorded them mevertheless, and in a suät by the wifie to recover the property it was helld that there thad mot theen a final and absolute deflivery, as the instrumemts were mot imitemalled to

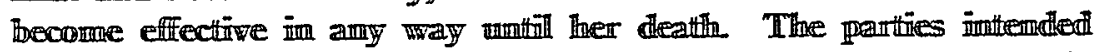

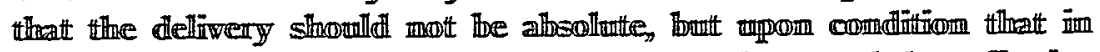

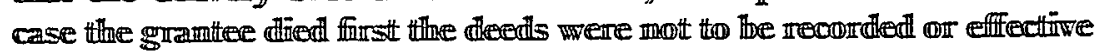

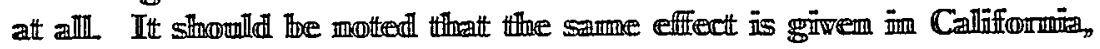

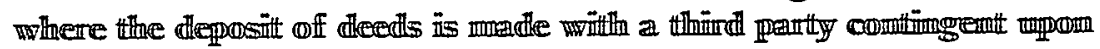

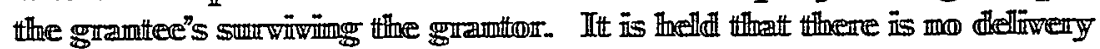

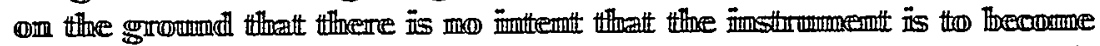

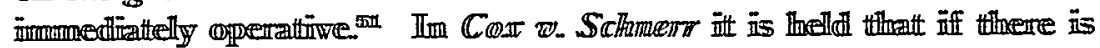

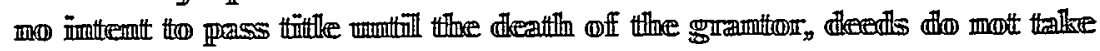
effect for waimit of dellinvery

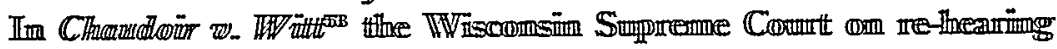

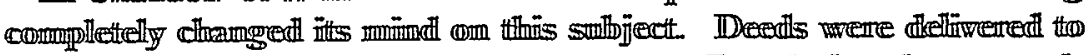

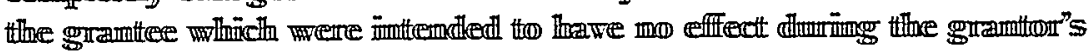

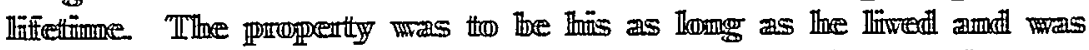

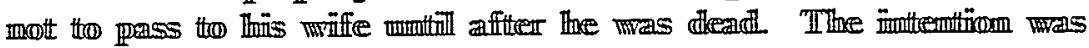

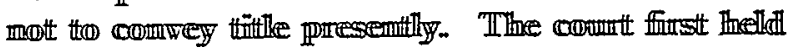

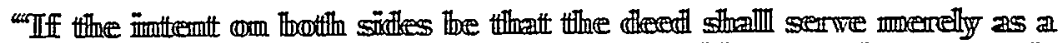

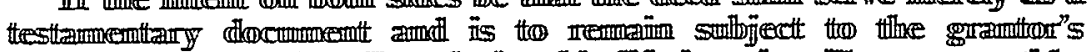

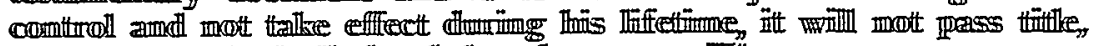

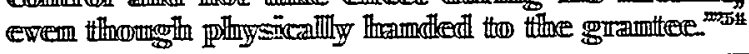

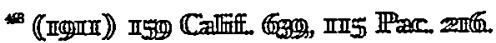

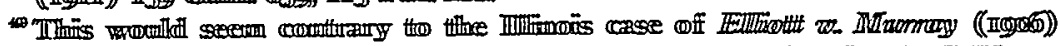

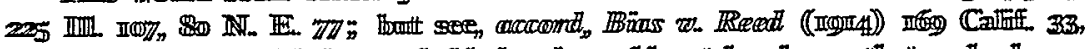

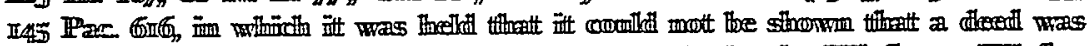

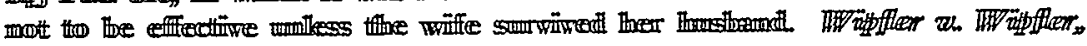
saupmen.

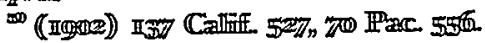

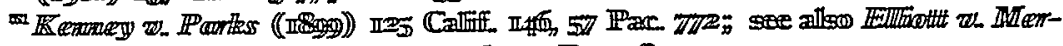

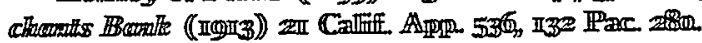

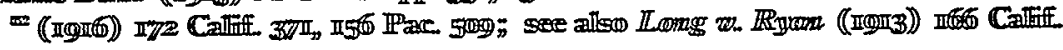
442 , I37 Pace

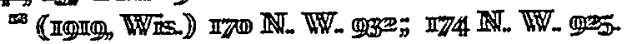

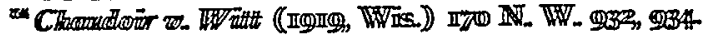




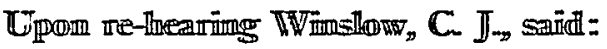

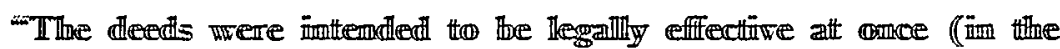

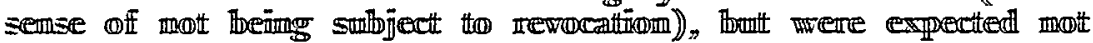

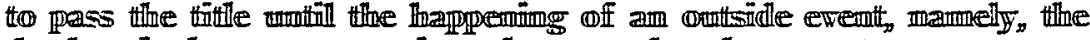

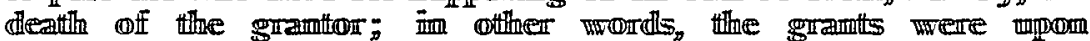
comadifition.

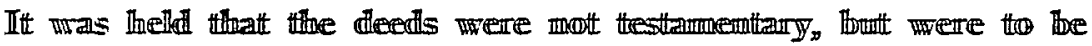

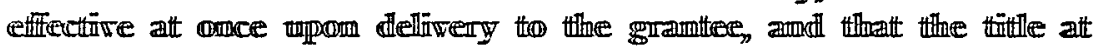

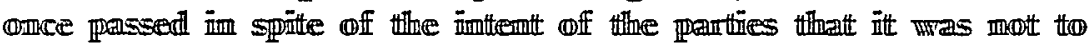

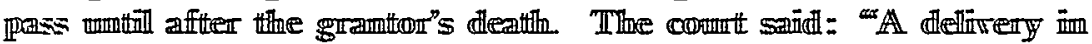

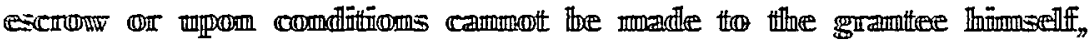

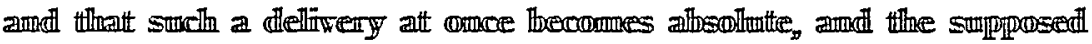

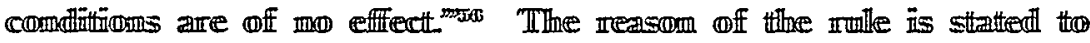
the thentt

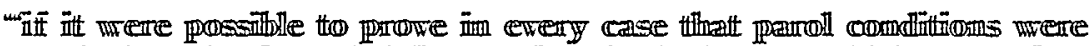

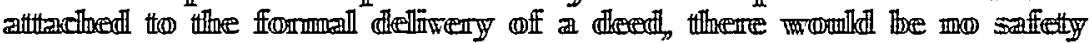

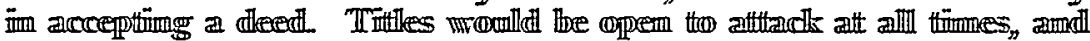

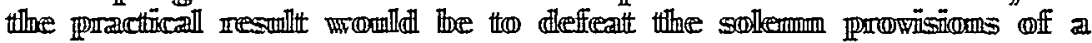

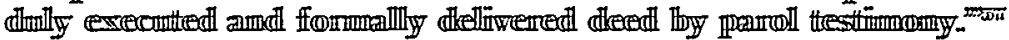

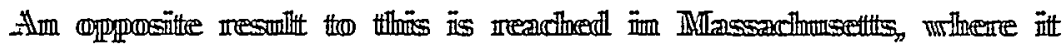

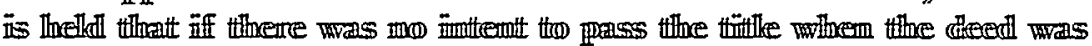

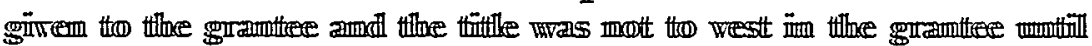

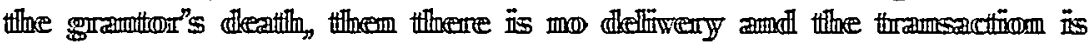

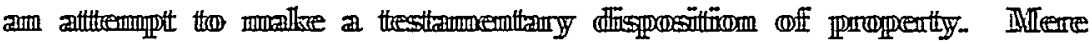

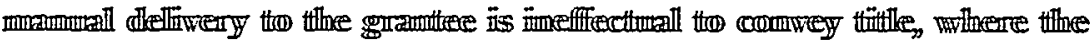

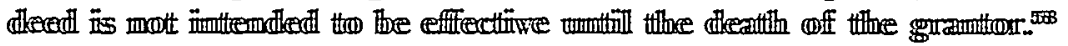

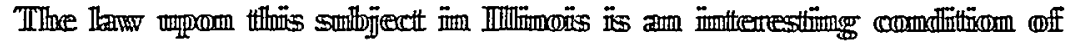

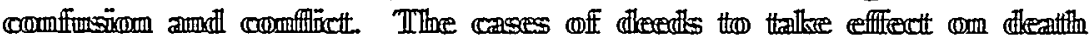

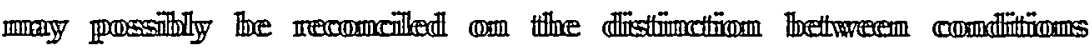

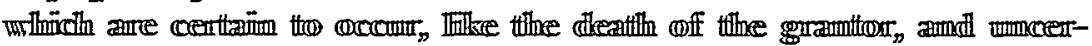

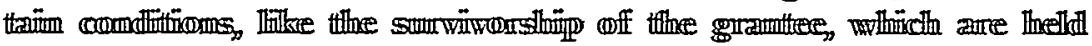

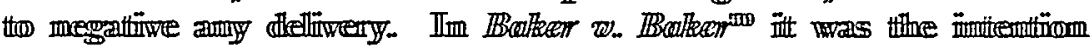

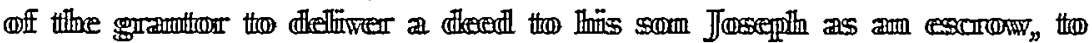

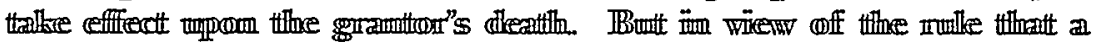

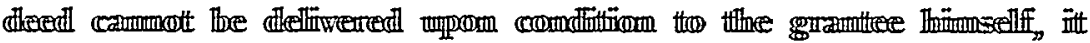

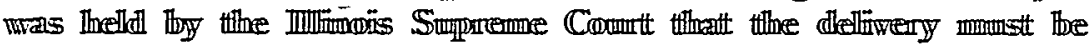

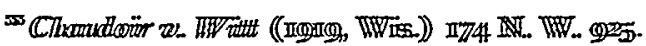

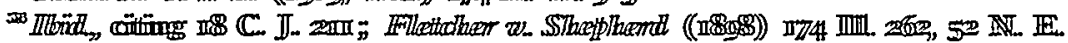

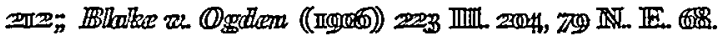

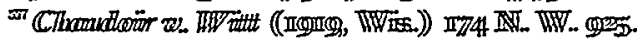

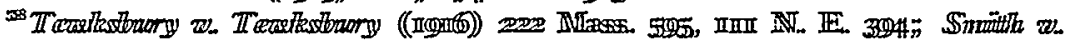

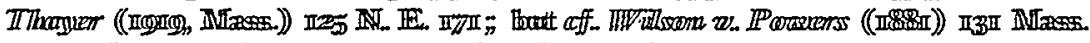

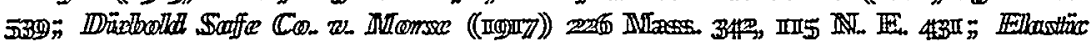

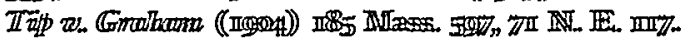

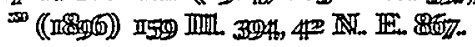


regarded as absolute. The deed, though limited by parol to take effect only upon the death of the father, went into effect at once. In Elliott $v$. Murray a deed was signed and acknowledged by the wife and handed over to her husband, the grantee, who placed it in his private box where it remained until after her death. It was made with the intention that it should take effect only in case the grantee survived the grantor; and in the event that the wife should survive him, it was never to take effect but was to be destroyed. The wife died first in the Iroquois Theater disaster. It was held that the possession of the deed by the grantee did not operate to vest title to the land in him. It was urged that such delivery of the deed should be held to invest him with title regardless of the intention of the parties, on the ground that a deed cannot be delivered to the grantee in escrow. It was held, however, that the parol condition precedent defeated delivery entirely. "A deed must take effect immediately upon its execution and delivery to the grantee or it will not take effect at all."

We accordingly find that in some cases the courts hold that conditional delivery is incomplete delivery and the condition precedent postponing the transfer of title until some future event negatives delivery entirely. There is said to be no delivery where the grantor did not intend that the title should presently and unconditionally pass to the grantee. ${ }^{61}$ In other cases where the court finds that there was an "actual delivery" of the deed to the grantee, it is held that title will pass at once notwithstanding a verbal understanding that the deed was to take effect on, or be subject to, certain parol conditions." 62

The act of delivery and the physical document are some of the operative facts. Both are essential to affect legal relations. There is obviously some inherent difficulty to incorporate in the deed itself evidence of its own delivery. Delivery is the final expression by word or act of assent to the instrument as the deed or contract of the party. The doctrine that there can be no delivery in escrow to the grantee or obligee is not a mere survival of the primitive doctrine that intent is immaterial so long as there is the physical act of surrender of the instrument. ${ }^{63}$ The problem is a difficult and baffling one. May there be a partial delivery, and may the extent to which

${ }^{10}$ (I906) 225 I11. I07, II2, 80 N. E. 77.

or Phelps v. Pratt (I906) 225 I11. 85 , 9I, 80 N. E. 69, 9 L. R. A. (N. S.) 945 ; Weber v. Brak, supra; Stanley v. White (1896) I60 Ill. 605, 43 N. E. 729; Roundtree v. Smith (I894) $5_{52}$ Ill. 493, 38 N. E. 680; Price v. Hudson (I888) I25 I11. 284, 287, I7 N. E. 817; Diebold Safe etc. v. Morse, supra.

${ }^{62}$ Blake v. Ogden, supra; Baker v. Baker, supra; Ryan v. Cooke (I8g8) I72 Ill. 302, 50 N. E. 2I7; see Riley v. International, etc. Co., supra; Reed v. Reed (I9I8) I17 Me. 28x, I04 Atl. 227, (I9I9) 28 Yale Law JourNal, 766.

${ }^{\natural} C f$. I Williston, Contracts (I920) sec. 210; Aigler, op. cit., 3I4; Tiffany, op. cit., 390, 39I. 
the instrument shall become binding be limited by a condition attending its delivery? The effect of delivery depends on an oral expression of intent and the intent expressed may be qualified or conditional on future events. The true function of delivery, however, is to declare that a written instrument shall be presently operative, not to prescribe the estates which the instrument shall grant whether vested or contingent, present or future. Such provisions may well be required to be incorporated in the deed itself. How far can you juggle with delivery to make the operation of a deed which purports to be absolute conditional only? Shall you allow the grantor, under the guise of qualifying delivery, in effect to incorporate provisions in the deed which vary its legal effect?

In order to supply tangible evidence of the qualification imposed on the delivery, the common law has attempted to require, at least in the case of deeds, delivery to a third person, under penalty of holding direct delivery to the grantee not conditional but absolute. If a deed is delivered upon condition to the grantee or obligee himself, extrinsic evidence of the condition conflicts with the strong presumption of absolute delivery arising from possession of the document. ${ }^{64}$ If the instrument is delivered to a third party, this supplies both direct and circumstantial evidence of the qualification placed upon the delivery. It withholds from the grantee the evidence of his right. It marks a qualification upon the acquisition of rights, privileges, etc., by him. It provides a third party as witness or stakeholder, who is supposedly a more or less indifferent person as between the grantor and grantee.

The law has the uncomfortable choice among three alternatives: (r) either to say there is no delivery, as some cases do; or (2) to hold that delivery is absolute, as other cases do; or (3) to give effect to the conditions, as most courts do in the case of documents not under seal. This choice cannot be made as a dry matter of logical deduction as to whether you can get around the parol evidence rule, but involves a question of policy. Which alternative on the whole is preferable,- to hold the grantor to something to which he never assented, or to defeat the transaction entirely, or to allow the condition and permit contracts and conveyances to depend on the memory and truthfulness of witnesses as to matters which ought to be incorporated in the instrument? There is no solution of the problem that is satisfactory under our present system of conveyancing. None of these alternatives will carry out the intent of the parties and at the same time preserve the stability of legal transactions. Since it is necessary to go into parol evidence anyway, it would seem preferable to give effect to the parol condition and make the law of deeds and

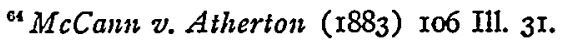




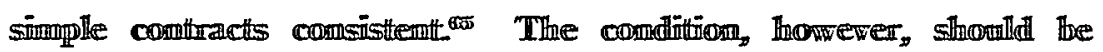

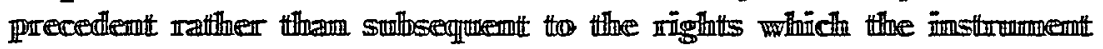

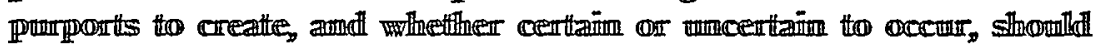

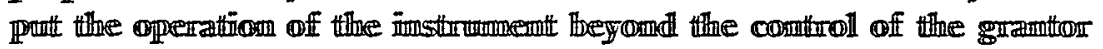
or obliggor.

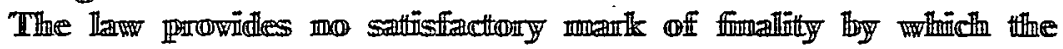

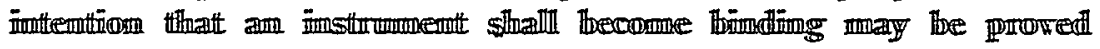

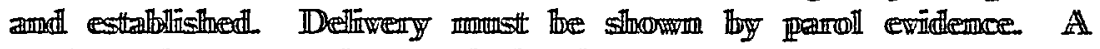

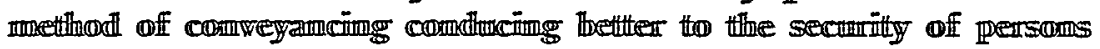

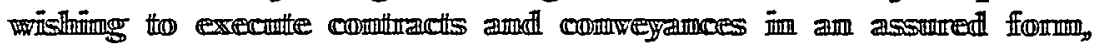

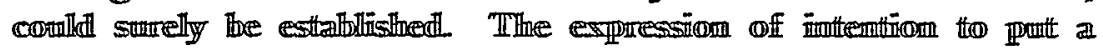

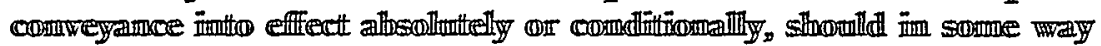

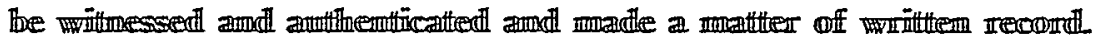

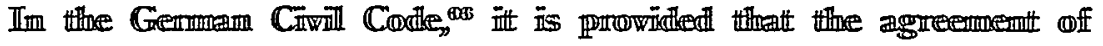

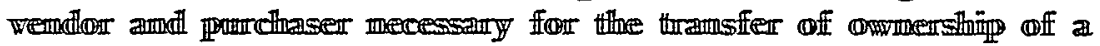

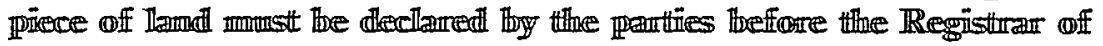

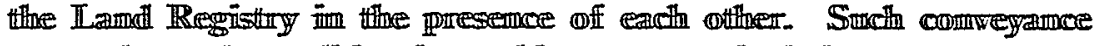

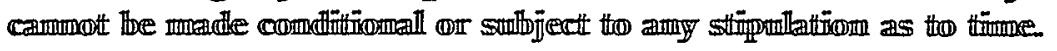

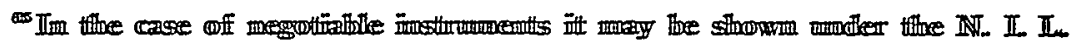

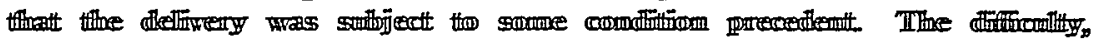

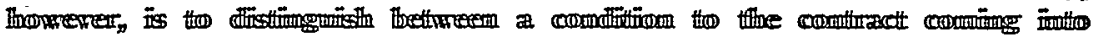

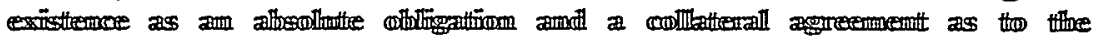

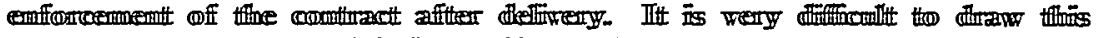

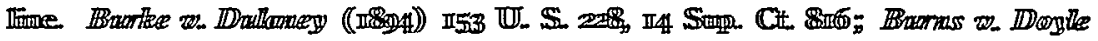

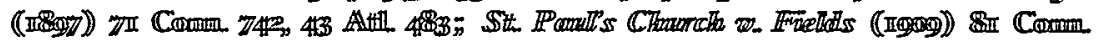

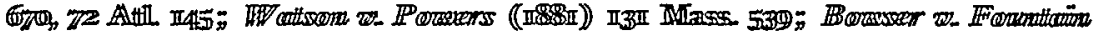

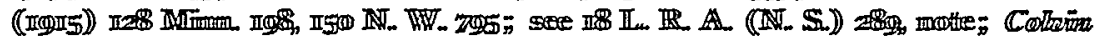

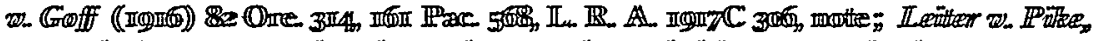

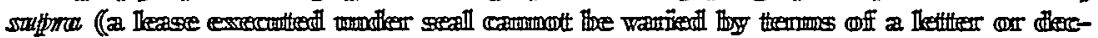

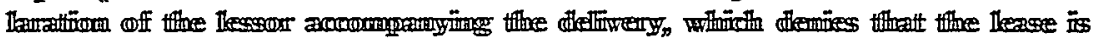

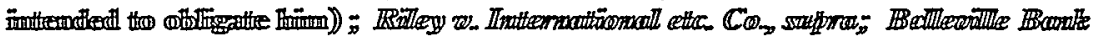

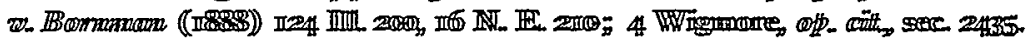

$\mathbb{S} \operatorname{sects}$ 